\title{
Performance and Intestinal Profiles of Tegal Duck Fed Ration Supplemented with Prebiotics
}

\author{
N. Iriyanti*, B. Hartoyo, \& S. Suhermiyati \\ Animal Nutrition Laboratory, Faculty of Animal Science, Jenderal Soedirman University \\ Jalan Dr. Soeparno 60, Purwokerto 53112, Indonesia \\ *Email of corresponding author: ningiriyanti@gmail.com \\ (Received 06-10-2017; Reviewed 02-11-2017; Accepted 13-01-2018)
}

\begin{abstract}
This research was aimed to determine the effects of prebiotics on performance and gastrointestinal profiles of Tegal ducks. One hundred two-month-old male Tegal ducks were distributed into 5 treatment groups; $\mathbf{R}_{0}=$ control; $\mathbf{R}_{1}=F O S ; R_{2}=$ MOS; $\mathbf{R}_{3}=$ Inulin; and $\mathbf{R}_{4}=$ natural prebiotic (water hyacinth/Eichhornia crassipes). The prebiotics were given at $0.2 \%$ of the total feed $(\mathrm{w} / \mathrm{w})$. The observed variables were performances and gastrointestinal profiles. This study used a completely randomized design and continued with honestly significant difference test. Performance (live weight, body weight gain, and feed intake) and intestinal profile (percentage weights of intestine, gizzard, crop, and pancreas) of ducks were not significantly affected by prebiotic supplementation in feed. FOS prebiotic and natural prebiotic from water hyacinth showed increased $(\mathrm{P}<0.05)$ the percentage of carcass and cecum weight compared to the other treatments. In conclusion, the use of different prebiotics resulted in relatively similar performances and digestive tract profiles except the percentage of carcass and cecum weight that increased by $4.5 \%$ and $36.67 \%$, respectively, with the supplementation of either FOS or water hyacinth.
\end{abstract}

Keywords: prebiotic, Tegal duck, performance, gastrointestinal profile, water hyacinth

\section{INTRODUCTION}

Duck is a type of waterfowl which is commonly reared by farmers in rural areas with the main purpose of producing eggs and meat. Duck is a native Indonesian duck with the capacity to produce meat and egg to fulfill animal protein demand (Yulianti et al., 2015). Ducks contribute 16\% egg and $2 \%$ meat in national demand (Ketaren, 2007). Duck farming is growing from rural to suburban area in Indonesia.

Male ducks are used because they are very potential as meat producers. The weight of male duck at the age of 8 weeks matches with consumers need and the meat has the best quality. Young male or female ducks that are marketed as livestock at 7 to 10 weeks old, are commonly called green duck.

Increasing livestock production is not only reached by giving the right amount of nutrient (quantity and quality), but also optimizing production by giving feed additives in the form of prebiotic, probiotic, antibiotic, et cetera. According to Kompiang et al. (2007), the most commonly used feed additive in commercial scale are sub-therapeutical and pharmaceutical-type antibiotics. Nowadays, however, health experts suggest that the use of antibiotics in sub-therapeutic level is the cause of the growth of antibiotics-resistant bacteria. Currently, the government has started to implement the reduction of antibiotics use. To overcome the reduction of antibiotic use which is needed as growth promotant, feed additive like probiotic is considerably safe. Prebiotics, a wellknown substance, can be used in order to support the growth promoting effect of probiotic.

Prebiotic is a non-digestible food ingredient which has good effects to improve the growth of one or more microorganisms in the colon. Prebiotic, in general, is a carbohydrate complex which is not digested nor absorbed in the intestine.

Various types of oligosaccharides, such as inulin, fructooligosaccharides (FOS), galactooligosaccharides (GOS), soya-oligosaccharides (SOS), xylo-oligosaccharides (XOS), pyrodextrins, isomalto-oligosaccharides (IMO), and lactulose, are commonly considered as prebiotics (Alloui et al., 2013). Prebiotic such as inulin, is a polydisperse carbohydrate material consisting of b- (2-1) fructosyl-fructose links (Roberfroid, 2010).

Oligosaccharides-prebiotic supplementation of the diets, such as FOS, may have an effect on improvement of microbial population in the rumen (Fernandez et al., 2010) and supplementation with GOS increases the growth of certain gastrointestinal bacteria, especially the lactic acid bacteria, Bifidobacteria, and/or their fermentation products such as short chain fatty acid (SCFA). SCFA production is an important physiological process of colonic microorganisms and may be useful in improv- 
ing gastrointestinal health by reducing the occurrence of diarrhoea through the modulation of microbiota (MacFarlane et al., 2008).

Inulin is a prebiotic derived from fructan carbohydrate that stimulates the activities and growth of beneficial gut bacteria, particularly Bifidobacteria and Lactobacili, and prevents colonization of pathogenic gut bacteria. FOS and inulin as prebiotics increase the absorption of nutrients through the improvement of mucose structure of the intestine (Rehman et al., 2007). The use of prebiotic (water hyacinth) is the most appropriate for duck, because water hyacinth is a waste product, very potential to be developed, and contains mineral and vitamins which support the development of male duck. The objective of the present experiment was to evaluate the effects of prebiotic use on gastrointestinal function.

\section{MATERIALS AND METHODS}

\section{Design, Animal, and Diets}

This experiment used 100 heads of two-month-old male Tegal ducks. The feed components were rice bran, corn, fish meal, soybean meal, methionine, and lysine. The feed components were purchased from PT. Cheil Jedang Superfeed Indonesia. The feed also contained palm oil, $\mathrm{CaCO}_{3}$, and premix. The feeds were formulated isoprotein and isoenergy with $18.47 \%$ protein and 2930 kcal metabolizable energy (ME)/kg. The detailed diets compositions are presented in Table 1. The chemical compositions of the experimental diets were analyzed according to AOAC (2006). During the experiment, feed and water were provided ad libitum.

\section{Experimental Diet}

The level of prebiotic used was $0.2 \%$ of the total feed $(w / w)$. Applied treatments were as follow: $R_{0}=$ Basal Feed as a Control; $\mathrm{R}_{1}=$ Basal Feed + FOS (Fructooligosaccharides); $\mathrm{R}_{2}=$ Basal Feed + MOS (Mannanoligosaccharide); $\mathrm{R}_{3}=$ Basal Feed + Inulin; $\mathrm{R}_{4}=$ Basal Feed + Prebiotic water hyacinth. Prebiotics were in powder form and mixed into the basal feed.

\section{Variables Measured}

The observation of intestinal profiles was performed at the end of the experiment, after treating the experimental Tegal ducks with experimental rations for two months. Therefore, the age of experimental ducks was 4 months or 16 weeks. The gastrointestinal profile analysis was conducted after treatment. The observed variables were duck's performance (daily weight gain, feed consumption, final weight, and carcass percentage) and intestinal profiles (the weights of intestine, caecum, crop, gizard, and pancreas). Eight hours prior to slaughtering, 10 ducks from each treatment were abstained from feed (2 ducks per replicate).

The final weight of the duck was weighted at the end of the experiment at the age of 16 weeks. Daily body weight gain was calculated by subtracting the final body

Table 1. Ingredients and chemical compositions of experimental diets (as-fed basis)

\begin{tabular}{|c|c|c|c|c|c|}
\hline Ingredient & $\begin{array}{c}\mathrm{R} 0 \\
\text { (Control) }\end{array}$ & $\begin{array}{c}\mathrm{R} 1 \\
\text { (FOS) }\end{array}$ & $\begin{array}{c}\mathrm{R} 2 \\
(\mathrm{MOS})\end{array}$ & $\begin{array}{c}\mathrm{R} 3 \\
\text { (Inulin) }\end{array}$ & $\begin{array}{c}\mathrm{R} 4 \\
\text { (Water Hyacinth) }\end{array}$ \\
\hline Corn, $(\%)$ & 47 & 47 & 47 & 47 & 47 \\
\hline Rice bran, $(\%)$ & 27 & 27 & 27 & 27 & 27 \\
\hline Soybean meal, (\%) & 13 & 13 & 13 & 13 & 13 \\
\hline Fish meal, $(\%)$ & 9 & 9 & 9 & 9 & 9 \\
\hline Coconut oil, $(\%)$ & 2 & 2 & 2 & 2 & 2 \\
\hline Premix,$(\%)$ & 0.75 & 0.75 & 0.75 & 0.75 & 0.75 \\
\hline Dicalcium-phosphate, (\%) & 0.75 & 0.75 & 0.75 & 0.75 & 0.75 \\
\hline Methionine, $(\%)$ & 0.35 & 0.35 & 0.35 & 0.35 & 0.35 \\
\hline Lysine, $(\%)$ & 0.15 & 0.15 & 0.15 & 0.15 & 0.15 \\
\hline Prebiotic, $(\%)$ & 0 & 0.2 & 0.2 & 0.2 & 0.2 \\
\hline Total, $(\%)$ & 100 & 100.2 & 100.2 & 100.2 & 100.2 \\
\hline \multicolumn{6}{|l|}{ Calculated nutrient contents } \\
\hline Crude protein, $(\%)$ & 18.472 & 18.448 & 18.448 & 18.448 & 18.448 \\
\hline Metabolizable energy, $(\mathrm{kcal} / \mathrm{kg})$ & 2929.2 & 2933.2 & 2933.2 & 2933.2 & 2933.2 \\
\hline Crude fat, $(\%)$ & 4.038 & 4.038 & 4.038 & 4.038 & 4.038 \\
\hline Crude fiber, $(\%)$ & 5.015 & 5.017 & 5.017 & 5.017 & 5.017 \\
\hline Calcium, $(\%)^{*}$ & 0.97 & 0.97 & 0.97 & 0.97 & 0.97 \\
\hline Available phosphorus, $(\%)^{*}$ & 0.50 & 0.50 & 0.50 & 0.50 & 0.50 \\
\hline Lysine, $(\%)^{*}$ & 0.79 & 0.79 & 0.79 & 0.79 & 0.79 \\
\hline Methionine, $(\%)^{*}$ & 0.55 & 0.55 & 0.55 & 0.55 & 0.55 \\
\hline
\end{tabular}

Note: The results of the analysis at the Laboratory of Animal Nutrition add Feed Science, Faculty of Animal Science, Jenderal Soedirman University. ${ }^{*}$ ) based on the calculation of NRC table (1994). 
weight with the initial body weight then dividing it with the number of nurturing days (final weight - initial weight)/(number of nurturing days).

Feed consumption was measured by subtracting the left-over and scattered feed from the original amount of given feed. At the age of 16 weeks, the ducks were slaughtered by cutting their jugular veins. Before slaughtering, the experimental ducks were not fed for 12 hours prior to slaughtering. The carcass data were obtained after the duck was slaughtered and cleaned from feathers, blood, viscera, head, and feet. The weight of each carcass was recorded and dressing percentage was calculated on the basis of dressed meat including giblets and skin. The heart, liver, gizzard, spleen, and pancreas were also weighed.

Carcass weight percentage was calculated by dividing carcass weight with living weight multiplied by $100 \%$. The percentage of intestine, caecum, gizzard, crop, and pancreas weights were obtained by weighing each organ then dividing each with living weight and multiplying the number by $100 \%$.

\section{Data Analyses}

At the beginning of experiment, the age of experimental ducks used was 8 weeks or 2 months because at this age the experimental ducks were readily adaptable to environtment and feed. The experiment was arranged in a completely randomized design, with 5 treatments and 5 replicates, consisted of 4 male Tegal ducks per replicate. The data were analyzed statistically with analysis of variance (ANOVA) and further test with honestly significance effect (Steel \& Torrie, 1994).

\section{RESULTS}

\section{Performance}

The final live weights of male Tegal ducks varied from $1184 \pm 80.81 \mathrm{~g} /$ duck (R1) to $1238.5 \pm 78.46 \mathrm{~g} / \mathrm{duck}$ (R4) with daily weight gains of $4.33 \pm 2.30 \mathrm{~g} /$ duck to $6.94 \pm 1.68$ $\mathrm{g} /$ duck (Table 2). These results were in line with the result reported by Mangisah et al. (2009) that daily weight gains of male Tegal ducks were around 6.56-8.19 g/duck.

The averages feed consumption across treatments were $101.45 \pm 2.45$ to $104.14 \pm 2.75$ (g/bird/day) and this range was within the normal range, while the feed consumption of local male ducks at the same age was $107.14 \mathrm{~g} / \mathrm{bird} /$ day. However, the range of average feed consumption was around 729.87 to 741.07 (g/bird/week). This feed consumption was equivalent to $102.27 \pm 1.09 \mathrm{~g} /$ bird/day that was far lower than feed consumption of ducks raised intensively (210-250 g/bird/day).

\section{Gastrointestinal Profile}

The use of different prebiotics did not significantly affect the percentage of intestine, gizzard, crop, and pancreas weights (Table 3). The weight percentages of intestine, gizzard, crop, and pancreas were $3.34 \pm 0.27 \%$ $4.04 \pm 0.65 \%, \quad 3.91 \pm 0.51 \%-4.97 \pm 0.24 \%, \quad 3.46 \pm 0.40 \%-$ $4.45 \pm 0.29 \%$, and $0.37 \pm 0.02 \%-0.40 \pm 0.04 \%$, respectively. These results were in line with those reported by Faishal et al. (2013) that 6-week male ducks supplied with mangosteen skin meal had the weight percentage of intestine, gizzard, crop, and pancreas around $3.05 \pm 0.35 \%$, $4.28 \pm 0.30 \%, 3.98 \%-4.58 \%$, and $0.40 \pm 0.05 \%-0.37 \pm 0.07 \%$, respectively. Rohmah et al. (2016) reported that 10 -week

Table 2. The performances of Tegal ducks fed prebiotic

\begin{tabular}{lccccc}
\hline & \multicolumn{5}{c}{ Prebiotic treatments } \\
\cline { 2 - 6 } \multicolumn{1}{c}{ Variables } & R0 & R1 & R2 & R3 & R4 \\
& (Control) & $($ FOS) & (MOS) & $\begin{array}{c}\text { R4nulin) } \\
\text { (Water hyacinth) }\end{array}$ \\
\hline Final live weight (g) & $1205 \pm 94.09$ & $1184 \pm 80.81$ & $1195.5 \pm 79.43$ & $1237.5 \pm 140.43$ & $1238.5 \pm 78.46$ \\
Daily weight gain (g) & $5.57 \pm 1.46$ & $4.33 \pm 2.30$ & $6.59 \pm 1.69$ & $6.93 \pm 1.19$ & $6.94 \pm 1.68$ \\
Feed consumption (g/bird/day) & $104.14 \pm 2.75$ & $102.13 \pm 5.93$ & $101.52 \pm 6.22$ & $102.09 \pm 5.56$ & $101.45 \pm 2.45$ \\
Carcass (\%) & $57.14 \pm 3.52^{\mathrm{a}}$ & $59.55 \pm 1.99^{\mathrm{b}}$ & $57.72 \pm 5.21^{\mathrm{a}}$ & $58.19 \pm 2.27^{\mathrm{a}}$ & $59.75 \pm 1.97 \mathrm{~b}$ \\
\hline
\end{tabular}

Note: Means in the same row with different superscripts differ significantly $(\mathrm{P}<0.05)$

Table 3. Gastrointestinal profile of Tegal ducks

\begin{tabular}{lccccc}
\hline & \multicolumn{4}{c}{ Prebiotic treatments } \\
\cline { 2 - 6 } \multicolumn{1}{c}{ Variables } & $\begin{array}{c}\text { R0 } \\
\text { (Control) }\end{array}$ & $\begin{array}{c}\text { R1 } \\
\text { (FOS) }\end{array}$ & $\begin{array}{c}\text { R2 } \\
\text { (MOS) }\end{array}$ & $\begin{array}{c}\text { R3 } \\
\text { (Inulin) }\end{array}$ & $\begin{array}{c}\text { R4 } \\
\text { (Water hyacinth) }\end{array}$ \\
\hline Intestine (\%) & $3.34 \pm 0.27$ & $3.51 \pm 0.34$ & $3.95 \pm 0.80$ & $4.02 \pm 0.40$ & $4.04 \pm 0.65$ \\
Caecum (\%) & $0.30 \pm 0.03^{\mathrm{a}}$ & $0.41 \pm 0.05^{\mathrm{b}}$ & $0.32 \pm 0.05^{\mathrm{a}}$ & $0.29 \pm 0.06^{\mathrm{a}}$ & $0.40 \pm 0.04^{\mathrm{b}}$ \\
Gizzard (\%) & $4.20 \pm 0.19$ & $3.91 \pm 0.51$ & $4.18 \pm 0.71$ & $4.42 \pm 1.02$ & $4.97 \pm 0.24$ \\
Crop (\%) & $3.46 \pm 0.40$ & $4.05 \pm 0.53$ & $4.15 \pm 0.68$ & $4.20 \pm 0.79$ & $4.45 \pm 0.29$ \\
Pancreas (\%) & $0.37 \pm 0.02$ & $0.40 \pm 0.04$ & $0.38 \pm 0.02$ & $0.37 \pm 0.05$ & $0.38 \pm 0.03$ \\
\hline
\end{tabular}

Note: Means in the same row with different superscripts differ significantly $(\mathrm{P}<0.05)$; \% = Weight of organ $(\mathrm{g}) /$ body weight of sampling duck $(\mathrm{g})] \mathrm{x}$ $100 \%$. 
male ducks supplemented with soursop leaves meal had weight percentages of intestine, gizzard, and pancreas in the ranges of $3.796 \%-5.946 \%, 3.786 \%-5.355 \%$ (with average of $4.571 \pm 0.785 \%$ ), and $0.25 \%-0.442 \%$ (with average of $0.349 \pm 0.093 \%$ ), respectively.

Experimental ducks supplemented with FOS prebiotic had the highest weight of caecum about $0.29 \pm 0.06-0.41 \pm 0.05 \% \quad(\mathrm{P}<0.05)$. This result was in line with that reported by Rohmah et al. (2016) that the average percentage of intestine weight was $0.286 \pm 0.106 \%$ within the range of $0.186 \%-0.387 \%$.

\section{DISCUSSION}

\section{Performance}

Final weights, daily weight gains, and feed consumptions were not significantly affected by prebiotic supplementation (Table 2). These nonsignificant effects could be related to the age of treatment. At the age of 8 weeks, experimental ducks supplemented with FOS, GOS, inulin, and water hyacinth were still used these prebiotics for bacterial growth in the digestive tract, to produce active ingredients to balance microbes in digestive tract like bacteriocin, to gain energy to fight against patogenic bacteria in getting food, and to form colony in intestines villi. It is the role of probiotic to maintain duck's health and immune system. Digestive tract microbes, especially Lactic Acid Bacteria (LAB) are not optimal in producing enzymes in digestive tract so the nutrient absorbtion is not optimal.

Different prebiotics used in this study resulted in different carcass percentages that ranged from $57.14 \pm 3.52 \%$ to $59.55 \pm 1.99 \%$. Analysis of variance results showed a significant difference $(\mathrm{P}<0.05)$ in carcass percentages indicating that prebiotics had varied responses to the growth of probiotic microbes and therefore causing disparity in carcass percentages. Carcass percentage in this research was lower than $60.77 \%-61.91 \%$ reported by Pratama et al. (2012).

The use of prebiotic FOS and water hyacinth were able to produce the highest carcass percentage, because FOS and water hyacinth could be used optimally for the growth of microbes in the digestive tract that optimalized nutrient absorption. Fructooligosaccharides (FOS) is a non-structural carbohydrate with $\beta$ - (2-1) fructosyl units that are undegradable by the enzymes in the small intestines, so the units will reach caecum and are further degraded by microbial enzymes. Inulin is the prebiotic that is frequently used in research for animal or human because of its high availability, safety, and higher nutrient absorbability (Roberfroid et al., 2010).

Supplementation of the diets with prebiotic oligosaccharides such as FOS, may have an effect to improve rumen microbial population, including a reduction in Salmonella colonization. This chance suggests that supplementation of diet with FOS might have been a viable option in both Salmonella control and antibioticfree programmes (Charalampopolus \& Rastall, 2009). Performance parameters in broilers have been evaluated with prebiotic supplementation. In parallel, body weight gain, feed conversion, and carcass weight were improved by prebiotic supplementation (Józefiak et al., 2008).

Feeding supplementation of inulin and FOS to broilers might have increased the absorption of nutrients by improving the intestinal mucosal structure, and increasing villus height (Rehman et al., 2007). Total SCFA and lactic acid concentrations are more often increase during the decrease of intestinal $\mathrm{pH}$ as a result of prebiotics supplementation. Regarding intestinal morphology, increasing the height of intestinal villus was reported when prebiotics were included in the broiler diet (Baurhoo et al., 2007). Other changes of intestinal characteristics have been observed, including an increase in rumen length.

Ducks supplemented with $50 \mathrm{~g} / \mathrm{duck} /$ day water hyacinth in feed showed a highly significant increase $(\mathrm{P}<0.01)$ about $5.86 \%$ in feed intake, $9.79 \%$ in egg laying rate, and $2.36 \%$ in egg weight compared to those of control ducks without prebiotic supplementation with a relatively similar feed conversion (Jianbo et al., 2008). Water hyacinth contains moderate crude protein $(11.2 \%)$, nitrogen free extract $(47.2 \%)$, and metabolic energy $(2028.5 \mathrm{Kcal} / \mathrm{kg})$. Water hyacinth was a potential feed for livestock especially during scarcity period (Hossain et al., 2015).

\section{Gastrointestinal Profile}

The weights of intestine, gizzard, crop, and pancreas were not significantly affected $(\mathrm{P}>0.05)$ by prebiotics supplementations. The use of prebiotic did not affect the percentage of intestine weight because the intestine of mature duck is no longer developing, particularly the villi. The contributing factors to the development of intestine in the experimental ducks are age, level of feeding, type and nutrient contents of feed, and live weight of experimental ducks. The main function of small intestine is feed digestion and nutrients absorptions.

The carrying capacity of digestion process on feed and nutrient absorption is affected by the area of epithelial intestine, epithelial folds, the height of villi, as well as the amount of villi and microvilli that broaden the area of absorption (Ruttanavut et al., 2009). The process of nutrient absorption is also affected by the height and breadth of the villi, duodenum, jejunum, and ileum (Sugito et al., 2007).

Crude fiber is one of the nutrients in the duck's feed that affect the intestine weight because crude fiber stimulates peristaltic movement of digestive tracts to secure the ease of digestive process. The activity of digestive organs will increase as the capacities of digestive organs are intensified. Crude fiber in feed has low digestibility and in certain amount will make the intestine work harder and thicken the intestine wall that eventually increases the weight of intestine (Sandi et al., 2012).

The weights of gizard, crop, and pancreas were similar in control and treatments groups. The nonsignificant effects of prebiotics supplementations on the weights of gizzard, crop, and pancreas are due to the types of those organs that are not inhabited by microbes which are benefited by the use of prebiotic. 
Gizzard is located between proventriculus and the duodenum that functions as the mechanical digestive organ that reduces the particle size of incoming feed through the contraction of smooth muscle in gizzard with the presence of grits and is one of the digestive organs that serves as temporal food reservation.

Purba \& Prasetio (2014) showed that there is a tendency of increasing weight of gizzard along with the increased crude fiber content of diet. The function of gizzard in poultry including duck is to grind and crush food (mechanical process) with the help of enzymes, for example lipase, before the food moving to the intestine. The level of crude fiber in the ration provides a significant difference $(\mathrm{P}<0.05)$ in the weight of gizzard. High level of crude fiber in the ration causes the increased load of gizzard in grinding food and the gizzard becomes thicker because of the more active muscle contraction of the gizzard (Sutrisna, 2011).

Svihus (2014) stated that the size of gizzard is mainly influenced by feed particle and fiber components, while the digestibility is affected by feed retention time and gizzard $\mathrm{pH}$. Besides the longer retention time, gizzard $\mathrm{pH}$ and fibre-rich feed might increase pepsin secretion and amylum digestibility (Sacranie et al., 2012).

The increasing activity of gizzard to digest food causes a vigorous contraction of gizzard muscle that thickens gizzard tendon and increases the weight of the gizzard. This activity occurs when duck is fed with high crude fiber. Besides age, the other contributing factors to gizzard development is the size of feed particle. The larger the particle, the harder the work of gizzard and the higher the weight of gizzard.

The crop is a digestive organ which only functions as temporary feed storage before it goes to the intestine, while pancreas produces pancreatic juice which contains digestive enzymes. Crop in duck is not developed as well in chicken. The function of crop in ducks is a temporary storing of feed, and the remaining feed in the crop can induce illness. Prebiotic supplemented in the diet of ducks is not stored in the crop so the weight of the crop does not increase. The development of crop is affected by feeding rate.

A faster crop development is found in birds eating fresh forage. Crop is the modified crop layered with folds of thin epithelium, contains mucosal gland to wet and smooth ingluvies wall and serves as lubrication fluid to soften the feed. Wet feed is easier to excrete than the dry feed. Tunica muscularis in the crop play roles in the process of feed softening so that the feed is thoroughly digested, therefore it needs a stronger and more solid crop structure. Accordingly, the structure of tunica mucularis of the crop in ducks consists of longitudinal and circular bundles of smooth muscle (Zainudin et al., 2014)

Pancreas is a digestive organ that produces digestive enzymes that include lipase, amylase, and protease which convert lipid, starch, and protein, respectively, into a less complex nutrients namely fatty acids, glucose, and amino acids. Prebiotic supplementation does not affect pancreas performance because the performance is affected by feed nutrient contents and anti-nutrition in feed including tannin, B-glucan inhibitor, and tryp- sin inhibitor. The activity of pancreatic enzymes are also influenced by the age of cattle, amino acids, and cholecystokinin.

The activity of pancreatic enzymes, lipase, amylase, and trypsin increased in chickens supplemented with prebiotics and synbiotics because of the presences of microbial enzymes, exocrine enzymes, and zymogen in the pancreas (Pruszynska-Oszmalek et al., 2015).

Rohmah et al. (2014) stated that the weight of pancreas is not affected by the presence of relatively small amount of tannin and saponin in the diet. Pancreas is an organ which produces digestive enzymes, and the presence of tannin or saponin can cause the increase in the weight of pancreas because of the work of lipase in fat digesting process and the increase of bile salts in fat absorbing process (Faishal et al., 2013).

Four-time feeding highly significantly $(\mathrm{P}<0.01)$ increased body weight and body weight gain percentage compared to two-time feeding in mule duck than in Muscovy ducks. Pancreas weight and percentage was significantly higher $(\mathrm{P}<0.01)$ in mule ducks $(9.56 \pm 0.17 \mathrm{~g}$, $0.17 \pm 0.01 \%)$ than those in Muscovy ducks $(7.71 \pm 0.30 \mathrm{~g}$, $0.14 \pm 0.01 \%$ ) because of different levels of feed intake in each duck (El Sayed et al., 2013).

The use of FOS prebiotic produced the highest percentage of cecum weight $(0.41 \pm 0.05 \%) \quad(\mathrm{P}<0.05)$, because FOS (fructooligosaccharide) is a nonstructural polysaccharide that can be digested by cellulolytic and hemicellulolytic microbes in cecum. FOS supplementation makes the cellulolytic microbes in the cell wall form a colony that eventually increases the weight of cecum.

The unconsumed prebiotics would have been digested by cellulolytic microbes in the caecum. The weight of normal intestine was around 30.21-39.79 $\mathrm{g}$ or $2.33 \%-3.29 \%$ of live body weight (Nena et al., 2013).

With the addition of FOS, the weight of caecum increased. This happened due to cellulolytic microbes in the caecum are able to digest carbohydrate/polysaccharide complex including FOS. Roberfroid (2010) reported that the other benefits of FOS were: (1) increasing adaptation ability of good bacteria in the colon, (2) decreasing the number of Clostridium perfringens in the digestive tract and intermediate product of food putrefaction process in urine and feces, (3) decreasing toxic metabolites and unneeded enzymes. Digesting process of 3-6g of FOS and GOS per day could decrease toxic substance production in the digestive tract and unnecessary enzyme as much as $44.6 \%$ and $40.9 \%$, respectively, (4) preventing diarrhea caused or not caused by pathogenic bacteria.

Proliferation of cecum epithelium causes the increase in the weight of cecum. The higher production of VFA may affect organ proliferation and is assumed to cause organ thickening and increased weight (Sutrisna, 2012).

The prebiotic can be selectively fermented by a certain probiotic and other beneficial gastrointestinal microbiota into short-chain fatty acids (SFCA), mainly acetate, propionate, and butyrate, that lowered the luminal $\mathrm{pH}$ and decreased pathogenic bacteria (Pourabedin \& Zhao, 2015). Prebiotics are non-digestible substances that provide a beneficial physiological effect on the host 
by selectively stimulating the favorable growth or activity of a limited number of indigenous bacteria (Sekhon \& Jairath, 2010).

\section{CONCLUSION}

The use of different prebiotics resulted in a relatively similar performances and digestive tract profiles except the percentage of carcass and the weight of cecum that increased by $4.5 \%$ and $36.67 \%$, respectively, with the supplementation of either FOS or water hyacinth.

\section{ACKNOWLEDGEMENT}

This project was funded by Ministry of Research and Tecnology and Higher Education of The Republic of Indonesia through "Hibah Kompetensi 2015: program"

\section{REFERENCES}

Alloui, M.N., W. Szczurek, \& S. Świątkiewicz. 2013. The use fulness of prebiotics and probiotics in modern poultry nutrition: a review. Ann. Anim. Sci.13: 17-32.

AOAC. 2006. Official Methods of Analysis of AOAC International. 18th ed. Assoc. Off. Anal. Chem., Arlington.

Baurhoo, B., A. Letellier, X. Zhaoand, \& C. A. Ruiz-Feria. 2007. Cecal populations of lactobacilli and bifidobacteria and Escherichia coli populations after in vivo Escherichia coli challenge in birds fed diets with purified lignin or mannanoligosaccharides. Poultry Sci. 86: 2509-2516. https:// doi.org/10.3382/ ps.2007-00136

Charalampopolus, D. A \& R.A. Rastall. 2009. Prebiotics and Probiotics Science and Technology. Springer Verlag, New York, Vol.1: p. 516. https://doi. org/10.1007/978-0-387-79058-9

El-Sayed, El., Y. Mona, \& U. E. Mahrous. 2013. Influence of overfeeding on productive performance traits, foie gras production, blood parameters, internal organs, carcass traits, and mortality rate in two breeds of ducks. International Journal of Animal and Veterinary Science. 7:220-226.

Faishal, I. J., I.H. Djunaidi, \& E. Sudjarwo. 2013. Effect of addition mangosteen peel powder (garcinia mangostana.l) to feed on carcass and internal organs mojosari drake. Jurnal Brawijaya 5: 1-10.

Fernandez , F., M. Hinton, \& B. Van Gils. 2010. Dietary mannan-oligosaccharides and their effect on chicken caecal microflora in relation to Salmonella enteritidis colonization. Avian Pathol. 31:49-58. https://doi.org/10.1080/ 03079450120106000

Gong, J., W. Si. R.J. Forster, R.Huang, H. Yu, Y. Yin, C. Yang, \& Y. Han. 2007. 16S rRNA genebased analysis of mucosa-associated bacterial community and phylogeny in the chicken gastrointestinal tracts: from crops to ceca. FEMS Microbiology Ecology 59:147-157. https://doi. org/10.1111/j.1574-6941.2006.00193.x

Hossain. M.E., H. Sikder, Md. H. Kabir, \& S.M. Sarma. 2015. Nutritive Value Of Water Hyacinth (Eichhornia crassipes). Journal of Animal and Feed Research. 5:40-44.

Jianbo, LU, Zhihui, FU, \& Zhaozheng, Y. 2007. Performance of a water hyacinth (Eichhornia crassipes) system in the treatment of wastewater from a duck farm and the effects of using water hyacinth as duck feed. Journal of Environmental Sciences. 20: 513-519

Józefiak, D., S. Kaczmarek, \& A. Rutkowski. 2008. A note on the effects of selected prebiotics on the performance and ileal microbiota of broiler chickens. J. Anim. Feed Sci.17: 392-397. https://doi.org/10.22358/jafs/66633/2008
Ketaren, P.P. 2007. Peran itik sebagai penghasil telur dan daging nasional. Wartazoa 17: 117-127.

Kompiang, I. P., S. Supriyati, \& O. Sjofjan. 2007. Pengaruh suplementasi ragi laut terhadap penampilan ayam petelur. Jurnal Ternak Tropika 6:36-44.

MacFarlane, G.T., H. Steed, \& S. Macfarlane. 2008. Bacterial metabolism and health related effects of galacto-oligosaccharides and other prebiotics. J. Appl. Microbiol. 104: 305-344.

Mangisah, I., B. Sukamto, \& M. H. Nasution. 2009. Implementation of fermented eceng gondok in duck ration. J. Indon. Trop. Anim. Agric. 34: 127-133.

NRC. 1994. Nutrien Requirement of Poultry. The $9^{\text {th }}$ Ed. National Academic Press. USA

Nena, K. A., Ismoyowati, \& S. Mugiono. 2013. Perbedaan bobot dan persentase bagian-bagian karkas dan non karkas pada itik lokal (Anas plathyrincos) dan Itik Manila (Cairina moschata). Jurnal Ilmiah Peternakan 1: 1086-1094.

Pourabedin, M. \& X. Zhao. 2015. Prebiotics and gut microbiota in chickens. FEMS Microbiology Letters 362:1-8. https:// doi.org/10.1093/femsle/fnv122

Pratama I., Fatmawaty, \& D. Sulistiawati. 2012. Penampilan dan produksi karkas itik lokal jantan (Anas platyrhynchos) yang diberi pakan mengandung tepung limbah rumput laut (Eucheuma cottonii) fermentasi. J. Agrisains 13: 173-183.

Pruszynska-Oszmalek, E., Kolodziejski, P. A., Stadnicka, K., Sassek, M., Chalupka, D., Kuston, B., \& Bednarczyk, M. 2015. In ovo injection of prebiotics and synbiotics affects the digestive potency of the pancreas in growing chickens. Poult. Sci. 94: 1909-1916. https://doi.org/10.3382/ps/pev162

Purba, M, \& L.H. Prasetyo. 2010. Respon Pertumbuhan dan produksi karkas itik pedaging EPMp terhadap perbedaan kandungan serat kasar dan protein dalam pakan. JITV 19: 220-230

Rehman H., C. Rosenkranz, J. Böhm, \& J. Zentek. 2007. Dietary inulin affects the morphology but not the sodium dependent glucose and glutamine transport in the jejunum of broilers. Poult. Sci. 86:118-122. https://doi.org/10.1093/ ps/86.1.118

Roberfroid, M.B. 2010. Prebiotics and probiotics: are they functional foods. Am. J. Clin. Nutr. 71 (suppl):1682S-7S.

Rohmah, N., E. Tugiyanti, \& Roesdiyanto. 2016. Pengaruh tepung daun sirsak (Announa muricata L.) dalam ransum terhadap bobot usus, pankreas dan gizzard itik tegal jantan. (The effect of dried soursop leaf meal (Annona Muricata L.) in rations on weight of intenstine, pancreatis and gizzard of male Tegal Duck). Agripet 16: 140-146. https://doi. org/10.17969/agripet.v16i2.5957

Ruttanavut, J., K. Yamauchi, H. Goto, \& T.Erikawa. 2009. Effects of dietary bamboo charcoal powder including vinegar liquid on growth performance and histological intestinal change in Aigamo ducks. International Journal of Poultry Science 8:229-236. https://doi.org/10.3923/ijps.2009.229.236

Sacranie, A., B. Svihus, V. Denstadli, B. Moen, P. A. Iji, \& M. Choct. 2012. The effect of insoluble fiber and intermittent feeding on gizzard development, gut motility, and performance of broiler chickens. Poult. Sci. 91 :693-700. https:// doi.org/10.3382/ps.2011-01790

Sandi, S., R. Palupi, \& Amnesti. 2012. Pengaruh penambahan ampas tahu dan dedak fermentasi terhadap karkas, usus dan lemak abdomen ayam broiler. Agrinak 2:1-5.

Steel, R.G.D. \& J.H. Torrie. 1994. Principles and Procedures of Statistics. Mc Graw-Hill Book Co. Inc. Pub. Ltd. London.

Sekhon B.S., \& Jairath S. 2010. Prebiotics, probiotics \& synbiotics: an overview. J Pharm. Educ. Res. 1: 13-36.

Sugito, W. Manalu, D. A. Astuti, E. Handharyani, \& Chairul. 2007. Morfometrik usus dan performa ayam broiler yang diberi cekaman panas dan ekstrak n-heksana kulit batang “Jaloh" (Salix tetrasperma Roxb). Med. Pet. 30:198-206 
Sutrisna, R. 2012. Pengaruh beberapa tingkat serat kasar dalam ransum terhadap pekembangan organ dalam itik jantan (Effect of levels crude fiber in feed for developments visceral organs in male duck). Jurnal Penelitian Pertanian Terapan 12: 1-5.

Svihus, B. 2011. The gizzard: Function, influence of diet structure, and effects on nutrient availability. World's Poult. Sci. J. 67:207-223. https://doi.org/ 10.1017/S0043933911000249

Yulianti, D.L., P. Trisunuwati, O. Sjofjan. \& E. Widodo. 2015.

Effect of Andrographis paniculataa phytobiotic on consumption, feed conversion and Mojosari duck egg production. Int. J. Poult. Sci. 14: 529-532. https://doi.org/10.3923/ ijps.2015.529.532
Zainuddin, D. Masyitha, Y. Mulyana, \& Fitriani. 2014. Struktur histologi tembolok (ingluvies) pada unggas (the histological structure of the crop (ingluvies) in poultry). Jurnal Medika Veterinaria 8: 47-50.

Vasa1, F., K.B. Ricaud, M.D. Bernadet2, L. Cauquil, O. Bouchez6, S. Combes \& S. Davail. 2014. Overfeeding and genetics affect the composition of intestinal microbiota in Anas platyrhynchos (Pekin) and Cairina moschata (Muscovy) ducks. FEMS Microbiol. Ecol. 87 (2014): 204-216. 